\title{
Experiencing Change, Encountering the Unknown: An Education in 'Negative Capability' in Light of Buddhism and Levinas
}

\section{SHARON TODD}

This article offers a reading of the philosophies of Emmanuel Levinas and Theravada Buddhism across and through their differences in order to rethink an education that is committed to 'negative capability' and the sensibility to uncertainty that this entails. In fleshing this out, I first explore Buddhist ideas of impermanence, suffering and non-self (anicca, dukkha, and anatta, respectively), known as the three marks of existence, from the perspective of Theravada Buddhism. I explore in particular vipassana meditation's insistence on openness to the transient nature of experience and self, and the notion of 'encounter' that is implied therein. I then interweave this with Levinas's notion of an ethics of alterity. I argue that taken in tandem, both provide the condition through which another kind of ethical sensibility can be developed-that is, one that is attuned to our encounters with the world. In conclusion, the article reflects on how this sensibility as 'negative capability' can re-inform an ethics of educational practices, which are by nature themselves necessarily involved with change and uncertainty.

In a Dharma talk given in 2012, Buddhist scholar Stephen Batchelor notes that the practice of meditation cultivates a certain orientation to life, an appreciation and acceptance of its uncertainties and transient nature. He likens this to the poet John Keats's notion of 'negative capability', a phrase originally invoked in a letter Keats wrote to his two brothers in 1818: negative capability 'is when man is capable of being in uncertainties, Mysteries, doubts, without any irritable [impatient] reaching after fact \& reason ...'. There exists an openness to life that is not to be sutured over by our too quick search for definite answers and explanations; instead negative capability creates a space in which we can dwell and observe, a space of sensibility that is not dependent upon any explanation we can give it. For Keats, an artist such as Shakespeare lives with the state of uncertainty and doubt 
that accompanies lived experience, allowing it to inform his art. Words can neither fully capture this experience nor describe it in any positive sense. Words, such as Shakespeare's, can only ever approximate and be suggestive of such experience. Thus, 'negative' capability signals an approach to living that acknowledges a certain passivity and acceptance, while being unconcerned with encapsulating experience within neat categories of understanding. Yet, as a 'capability', the term also suggests an adeptness that can be developed, encouraged or learned. In comparing it to meditation, Batchelor intimates that negative capability becomes a skilfulness in patience, a learning to live with sensory experiences, thoughts and feelings without seeking to conceptualise them, or to 'own' them. ${ }^{1}$ This sensibility forms an orientation to one's encounters in the world that do not easily map onto the conventional ordering of the world as one based on certainty and factual knowledge. This version of the world is one that is so often presented in schooling contexts and yet such contexts are where the encounters between teachers and students and the world may often be quite messy.

So much of the focus in formal education, particularly in response to league tables and high-stakes testing, is consumed with the attainment of skills, the acquirement of competencies, and the procurement of facts. Whilst these might be relatively benign goals in themselves, when they are coupled with little or no appreciation for the existential vagaries and doubts that accompany living a life, schools risk failing to create possibilities for engaging students' wonderment and curiosity about their lived experiences. Education speaks a language, in other words, that seems far removed from Batchelor's (and Keats') observations of mystery and uncertainty as part of our sensible being in the world. Such being in the world is not rooted in the certainty of the self, or in one's clinging to fact or reason, but lies instead in an openness to what one cannot know and invites a mode of response proper to that openness. As Deborah Britzman remarks with respect to negative capability, 'we may begin to understand that living in the world requires our response to the world and our responsibility in the world is affected by our having to symbolize the world' (2009, p. 119).

There is thus a correlation between our response to the world and our responsibility to live well within it that hinges on learning how we are implicated through our relations to the world. What Britzman is intimating here is that living well with uncertainty and the vicissitudes of life is of both ethical value and educational significance. At what appears to be the opposite end of the spectrum, governments have recently been so caught up in measuring performance outcomes and fixating on school results, that the educational relations between teachers, students and what they are studying are seen increasingly in instrumental terms and less in terms of how they might contribute to an ethical engagement with life. As some of the articles in this issue suggest (see Hyland and O'Donnell), even mindfulness has sometimes been introduced under the banner of efficiency: better attention creates more focused learning on the task at hand. My worry is that there is little time or effort paid to the value of opening up to sensible experiences beyond what can be known through 'fact and reason'. If schools are not engaging youth in regard to their capacities to tolerate change, or to sustain 
an inner life that is also responsive to others, then it seems to me that their broader ethical role has been sacrificed on the altar of measureable results. Thus, the questions that guide my inquiry here are: what can openness to change and mystery offer to constructing ethical possibilities in education, and how might these act as an antidote to the increasing demand placed on students to be tested and measured at earlier and earlier ages? Moreover, how might such openness be both philosophically grounded and educationally practiced?

This language of openness and its connection to ethics is familiar territory for readers of the philosophy of Emmanuel Levinas. Indeed he, like the poet and the Buddhist, presents us with an image of ethical existence that is premised on a radical passivity and displacement of self that enables one to be open to the mystery of the other. Again, unlike educational endeavours that have turned to an episteme of certainty as their primary model of teaching and learning - despite the increasing fear of failure this brings on the part of students (O'Donnell, 2014) - for Levinas it is acceptance of the mystery of the other as an existent who is not fully knowable to the ego ${ }^{2}$ that enables another kind of teaching and learning: I 'learn' to become through encountering the strange and unfamiliar, allowing it to challenge me without an 'irritable reaching after fact and reason', as Keats would say. Levinas's work is pre-eminently about letting the otherness of the other be, without appropriating the other into frameworks of knowledge or understanding.

Although one might already anticipate some tensions between the Levinasian encounter with otherness and the Buddhist understanding of nonduality as dealt with in other articles in this issue (Eppert et al. and Sarath), I nonetheless think that these two philosophies can be read together in order to outline an education that can encourage a kind of spaciousness that leads to a responsible appreciation for others. My task here is to read Levinas and Buddhism across and through their differences, in order to rethink an education that is committed at least as much to sensibility, and all the uncertainties this entails, as it is to measurable forms of knowledge, which are largely defined by regimes of certainty and permanence. In fleshing this out, I first explore Buddhist ideas of impermanence, suffering and non-self (anicca, dukkha and anatta, respectively), known as the three marks of existence, from the perspective of Theravada Buddhism. I explore in particular vipassana meditation's insistence on openness to the transient nature of experience and self, and the notion of 'encounter' that is implied therein. I then interweave this with Levinas's notion of an ethics of alterity. I argue that taken in tandem, both provide the condition through which another kind of ethical sensibility can be developed - that is, one that is attuned to our encounters with each other. In conclusion, the article reflects on how this sensibility as 'negative capability' can re-inform an ethics of educational practices, which are by nature themselves necessarily involved with change and uncertainty

In the next section, I explore some key elements of Buddhist philosophy, from a Theravadan perspective, that form the basis of Dhamma practice and vipassana meditation, primarily drawing on sources from the Pali canon and its commentators in order to situate the ethical aspects of openness 
to our encounters with the world, which, as we shall see, also share deep resonances, as well as some disparities, with the conceptual framework of Levinasian ethics.

\section{PHILOSOPHY, MEDITATION AND DHAMMA PRACTICE: DUKKHA, ANICCA, ANATTA}

Vipassana (or Insight) meditation, sometimes loosely fitted under the umbrella term mindfulness, bases itself on developing awareness and an openness to sensible experience not unlike that discussed in the introduction above. The body of Buddhist teachings, or Dhamma (which means 'teachings' in Pali; Dharma in Sanskrit), is an ethical orientation to life of which meditation is one aspect, albeit arguably for some its most important one. Yet the word dhamma also has another meaning. It refers to phenomena, or categories of experience, which provide the grounds upon which we apprehend, encounter and act in the world (Anālayo, 2003). Thus, practicing the Dhamma, in terms of this double meaning, suggests that one's way of living is deeply connected to the phenomenal world as this world gives itself to us as a teaching. That is, engaging in the Dhamma puts us in a certain relation to the world around us that is open to the teachings it has to offer. Manu Bazzano (2013) writes:

Unlike mindfulness, Dharma practice is not a 'learned skill' (Bishop et al., 2011, p. 237) but a stance of openness to the teachings inherent in the dharmas, or phenomena - a form of schooling in the unexpected and the unfathomable, since life and the world are forever ambiguous and ungraspable (p. 138).

Vipassana meditation, on this view, is a grounded, embodied practice that both services and enables a much broader connection to the Dhamma as a way of life.

The whole impetus behind Dhamma practice in general and vipassana in particular is, as it is often put, the cessation of suffering ( $d u k k h a)$. Indeed, suffering in Buddhism is the inevitable condition of life. To live is to experience suffering. This does not mean that we are in a constant state of misery, but that the human condition is one that is imperfect and flawed ${ }^{3}$ and thus open to dissatisfaction and disappointment. A critic might say that when we experience feelings of joy or happiness we are not suffering; but the point is that like all moments of experience, joy and happiness pass and reveal their transient nature. It is this arising and passing away (anicca) that is the cause of our everyday hurts and anxieties; we suffer to the point that we wish to expunge the difficulties impermanence causes by installing and clinging to a sense of permanency. The changing nature of reality, full of uncertainties, instead becomes transformed into fixed positions; through fixity, we assuage the discomfort of the unknown. 'I know this is that' is a move to make the strange more comfortable and familiar. We seek, therefore, in the words of Keats once again, to reach after fact and reason, in order to subdue the anxieties (dukkha) that arise from doubts and uncertainty. 
There seems to be something intolerable about the idea of impermanence; not only in terms of how one's thoughts or emotional states come and go, but in terms of our own mortal existence. The Buddhist position is that we, as individuals and cultures, create illusions of permanence to ward off facing the painful vicissitudes of our humanity. Moreover, it is through making attachments to these illusions, and identifying with them, that we begin to form a sense of self. ${ }^{4}$ The Buddhist conception of the self is therefore wrought out of both the myriad relations we make in the world and the attachments we make to these relations. It is this impermanence (anicca) of the self to which the Buddhist term, anattā, or non-self, refers. Etymologically, 'an' is the negation of 'atta', or self. The point is that it is not only phenomena that are transient, but that the very self who engages with phenomena is such. Thus a sense of self is a result of a complex development, of what in Buddhist language is known as 'dependent origination': each of us is conditioned by our attachments to particular experiences, which give rise to further experiences that in turn condition our way of being in the world, and so on. On this view, we construct a sense of constancy out of our dependency, as a kind of sediment of the attachments we make to the phenomenal world. The self, on the Buddhist view, is very much a relational self. ${ }^{5}$

On this point, we would appear to come close to how many social constructionists, feminists, poststructuralists and psychoanalysts conceive of the self: that through our intersubjective relations with the world we form an ego, a subjectivity, and/or a deep sense of identity. An 'I', on these views, becomes constituted through narratives, discourses, fantasies, and power relations. Yet, where Buddhism is different from these positions is in its soteriological impulse to liberate the 'self' from suffering by disengaging from those attachments that keep alive a sense of permanency and the distress that arises from it. And this is where, as we shall see further below, meditation enters the arena: as a practice that seeks to enable this disengagement. While feminist and critical pedagogy, for example, might also seek liberation from oppressive conditions, they do so often by advocating an alteration of social relations in ways that can (re)install an alternative version of the self - as a fully conscious, emancipated self — and not necessarily by calling for a radical re-interrogation of the very notion of self as Buddhism does (see Hattam and Baker's article in this issue for how this is more in line with Foucault's stance) ${ }^{6}$ In Buddhism, the process of disengagement means that the very sense of self (not just of an oppressed or victimized self) becomes a process of unravelling and destabilisation. Disengagement brings one face to face with impermanence and challenges, for instance, conventional Western notions of agency.

In the Râhulasamyutta, the Buddha asks his interlocutor: 'Is what is impermanent, suffering, and subject to change fit to be regarded thus: "This is mine, this I am, this is my self?"' (Bodhi, 2000, p. 694). His unequivocal answer is 'no', and the simple reason he gives is because 'there is no self' (anattā). Since all form, feeling, perception, mind states and consciousness (what are known as the five aggregates) are impermanent, there can be no permanent or substantial self that can possibly emerge from this sea bed of 
constant change. What one experiences does not belong to a self because the only self there is is the one we have created as a result of those experiences. There is no a priori 'self'; no 'self' in the 'first place' or in the 'first instance'. A sense of self is without essence or substantiality; it is only constructed out of a series of experiences, a series of attachments. Thus, it is the experience that makes a self, not a self that has an experience. The common refrain in many of the Buddha's early discourses is: 'This is not mine, this I am not, this is not my self' (see the discourses in Nidana-vagga in Bodhi, 2000). It is not that the Buddha is suggesting that our experiences in this world would be more authentic if they aligned with a 'true' self, as if there were another self we could access through meditation, a transcendent self that exists in an eternal realm, such as we find in Brahmanic traditions. Rather, as Bikkhu Bodhi (2000) puts it: 'The Buddha declares that "all phenomena are nonself" (sabbe dhammā anattā), which means that if one seeks a self anywhere one will not find one' (p. 1457, n. 385). Thus claiming that 'feeling is nonself' or that 'consciousness is nonself', as the Buddha does (Bodhi, 2000 , p. 868), means that there is separation between, on the one hand, feeling or consciousness as we experience them and, on the other hand, their attribution to a 'me' who is doing the experiencing. Such attribution is only possible because there is no distinction between 'experience' and ' $m e$ '. There is thus a distancing required in pursuing liberation from suffering - a distancing not from the world as it is, but from the clinging to permanence which often constructs the world as we want it to be.

The Buddha's declaration that 'there is no self' is radical in the sense that it enables another kind of awakening to a self of transience and change. This, in turn, compels us to imagine responses to the world other than the usual ones dominated by our own habitual attachments. And because the self is part of a changing world, the idea of nonself creates another kind of relation not only to our selves, but also to the world. Nonself, in short, is a condition for an ethical relation. As Mitchell Verter (2013) puts it:

The realization that everything is always changing is a fairly common insight. Many Buddhist traditions, however, understand this observation not merely as knowledge about the ontological character of existence, but more importantly as something that leads to a type of ethical awareness. Realizing that all phenomena are radically contingent, radically interconnected, and radically impermanent alters our existential orientation toward the world. Once we understand the world is beyond our control and that we can never find our own selves in it, once we realize that we are vulnerable to both pain and pleasure - to both wounds and balms - we can begin to quell the attachment that causes us to suffer (p. 236).

To return to the practice of vipassana meditation within this broader conception of the Dhamma and the idea of nonself, means to situate it within the process of unknotting attachments and the subsequent displacement of self this gives rise to. That is, if practicing the Dhamma involves a way of life not only consistent with the Buddhist philosophical views of dukkha, 
anicca and anatta, but also with developing another kind of responsiveness to the world, as the Theravada tradition emphasises, then how one explores one's own experiences in the world becomes an eminently practical task.

\section{VIPASSANA PRACTICE AND THE ENCOUNTER}

This practical - and pedagogical - task is well captured in the Satipatthana Sutta, ${ }^{7}$ which is usually translated as the Discourse on the Foundations (patthana) of Mindfulness (sati). Here, there are clearly set out tasks that deal with the practicalities of becoming aware of bodily sensations, feelings, mind and dhammas (or categories of experience). In this, I read the text as a predominantly pedagogical one, focusing as it does on the transformation of self. One of the Sutta's key translators, Ven. Anālayo (2003), invites another interpretation of Satipatthana than that of sati (mindfulness, awareness) and patthāna (foundation or cause). Instead, he suggests that patthāna is based on upatthāna, meaning 'placing near', 'attending' and 'being present'. This suggests, for Anālayo that sati is something that 'stands alongside of', or is 'in the presence of', and taken together the terms suggest more a sense of 'attending with mindfulness' or 'presence of mindfulness' which is consistent with the content of the Sutta. ${ }^{8}$ Mindfulness, however, is not only about awareness, but also embodies a sense of the past and memory, since sati is also related to the verb sarati, to remember. Sati denotes a practice of recollection. This means that sati is about calling something that is remembered into presence, with a certain kind of attentiveness. When we are mindful of something - our breathing, for example - we approach it with a sensitivity, a carefulness, perhaps even a tenderness. Even in ordinary speech when we say we ought to be mindful of someone's circumstance, there is a kind of remembering involved that recalls to the present moment something we know about that person's life. It is not the knowledge or awareness of that circumstance per se that matters, but the calling up and drawing of attention to it in the moment so that it shifts the relation to that person. This is where vipassana meditation as a practice of satipatthana entails a form of ethical attention that simple cognition or consciousness alone cannot bring forth. Vipassana, therefore, is not merely about observing and then deducing an ethics from what one sees (which would be akin to establishing an ought from an is), but instead is about developing attentive awareness in one's encounter with a phenomenon - be this phenomenon a feeling, a thought or another person. For Joseph Goldstein, from the outset vipassana 'rests on our understanding of the ethical dimensions of mindfulness' (2013, p. 63). Yet, in order to develop this capacity, the ego needs to step out of the way, as it were, and subject its own attachments to the movements of attentive awareness. Vipassana encourages a letting go of those attachments, which means a letting go of the ego. This letting go, it is to be remembered, is part of a larger Dhamma practice. That is, it is part of a way of life whereby my capability to deposition my ego with attentive awareness is necessary for living my life well with others.

In this letting go, we can see the parallels with negative capability as an openness to the uncertainty of my very sense of self as I encounter the 
world. Paradoxically, what vipassana meditation suggests is that openness to the encounter with my experiences and with the world around me is actually made possible by a subtle effort (a capability, if you will) to be open: openness would seem, on the one hand, to be called up, or called forth, in order for us to be attentive and yet, on the other hand, it is also the result of our attentiveness. This paradox in part arises, it seems to me, because the 'encounter' in Theravada Buddhism - that is, the experiential point of contact with the world through our senses - is not wholly conceived as a provocation of openness, but is, rather, considered to be a state of affairs to which attentive awareness is drawn. That is, the encounter does not 'act' on me independently of what I might feel or think about it. What I instead wish to suggest, in interweaving conceptions of the nonself with Levinas's ethics of alterity, is that the encounter itself (not our attitudes that predate it or arise with it) incites the very possibility of openness and receptivity. The encounter, as we shall see further below, like the dhamma for Buddhism, is what gives rise to teaching. It is through our encounters that we 'learn to become' (Todd, 2003), and it is also through our encounters that we unlearn our identity. Thus, the question is: does an encounter with the world entail a Buddhist notion of activity or effort through applying attentive awareness, or is the encounter a Levinasian one experienced as a radical passivity, even to the point of 'traumatism' (Levinas, 1969, p. 73)? This might seem a subtle distinction to make, and a rather abstract one at that, but I think it is a worthwhile distinction to pursue within the context of the educational field, where the primary relationships of teaching and learning are indeed predominantly ones of 'encounter'-between teacher, student and the stuff of knowledge. Thus, how we encounter our selves and our world through negative capability is not only an ethical question but is also an eminently educational one.

\section{NONSELF, ENCOUNTER AND THE ETHICS OF ALTERITY}

The Levinasian identity, ${ }^{9}$ like the Buddhist self, is born out of a condition of suffering. Suffering, for Levinas, is part of the very fabric of existing and it is a marker of one's inevitable solitude as a being, as an existent. He writes, 'In suffering there is an absence of all refuge. It is the fact of being directly exposed to being ... The whole acuity of suffering lies in the impossibility of retreat' (1987, p. 68). With no escape, the subject seeks 'mastery over itself' (p. 55); or better, it consolidates itself in order to master existence. The resultant identity (or ego) becomes an 'enchantment to itself'; it is 'occupied with itself' (p. 55). This process of identity formation becomes what Levinas (1969) will call in a later work a 'totality'. That is, in seeking to master existence the identity creates identifications that solidify into a 'me' that then sees itself as part of the social world of language and signification. 'The I is not a being that always remains the same, but is the being whose existing consists in identifying itself, in recovering its identity throughout all that happens to it. It is the primal identity, the primordial work of identification' (1969, p. 36-my emphasis). 
'All that happens' to the I, as in the Buddhist position, is dependent upon our changing relation to others and to the environment. We seek to avoid the solitude of suffering and so create identifications (or attachments in Buddhist terms) that form the 'substance' of our selves. Yet, Levinas claims that there is more to being and existence than this image of totality; there is always an otherness to the sameness of identity that the I has constructed for itself. Thus, there is a limit to our totality, and that limit is to be found not in a relation I create with myself, but only in a face-to-face encounter with the Other. The totality of the ego is challenged, according to Levinas, through an encounter with an other who is a separate existent from me.

It is banal to say we never exist in the singular. We are surrounded by beings and things with which we maintain relationships. Through sight, touch, sympathy and cooperative work, we are with others. All these relationships are transitive: I touch an object, I see the other. But I am not the other. I am all alone. It is thus the being in me, the fact that I exist, my existing, that constitutes the absolutely intransitive element, something without intentionality or relationship. One can exchange everything between beings except existing (1987, p. 42).

Thus, it is not that Levinas does not recognise relationships as part of the landscape of human interaction, but it is that such relationships are only possible between two - two subjects who are separate, irreducible in their existence. To assume to be the same as the other, for Levinas, is to colonise the other in an imperious move. Instead, the other is always more than me, more than the sum of my knowledge, more than I can possibly know. The Other challenges my totality because she is 'unknowable' and therefore escapes my intentionality. She resists my categorisation, my labelling, my 'understanding' of her - not through anything she says or does, but through her very being.

The relationship with the other is not an idyllic and harmonious relationship of communion, or a sympathy through which we put ourselves in the other's place; we recognize the other as resembling us, but exterior to us; the relationship with the other is a relationship with a Mystery (1987, p. 75).

This mystery marks a sense of unease because it calls the certainty of my identity into question. The encounter with the Other, in challenging my totality, brings with it what Levinas calls a 'traumatism of astonishment' $(1969$, p. 73$)$. It is a felt traumatism since it disturbs the very insularity the self has built up in its attempt to escape the suffering that accompanies existence. Moreover, this is not simply a cognitive exercise, a realisation or a dawning, but a sensate experience. That is, the encounter with the other cuts through consciousness and its deep hold on identity, and directly affects the body. For Levinas it is at this level of sensibility where the complacency of my ego is challenged and not at the level of 'fact and reason'. For Levinas, 'sensation is the breakup of all systems' (1969, p. 63). 
At this level of sensibility, the ego is provoked into transformation by an encounter that lies beyond our cognition and beyond our attempts to capture or comprehend the Other as an alter ego, as someone like me. Any attempt at explanation, through psychology or education or politics are, for Levinas, merely rhetoric. Instead, 'to renounce the psychoagogy, demagogy, pedagogy rhetoric involves is to face the Other, in a veritable conversation' (1969, p. 70). This conversation, however, is not simply of words but of a felt confrontation with the alterity that reveals itself to me. Thus the encounter occasions a kind of death for the ego, whereby 'we are no longer able to be able [nous ne 'pouvons plus pouvoir']. It is exactly thus that the subject loses its very mastery as a subject' (1987, p. 74). But for that death to take place, the other must become my 'first teaching', my first encounter with an infinity opened up not through my communion or unity with the other, nor through some thought I have about our similarities, but because the very otherness and mystery of the other opens before me in an engulfing limitlessness. It is in this way that the encounter incites a response.

What Levinas refers to in his later work as the 'proximity' to the Other becomes for him the condition for continual change. This 'proximity' is not an intellectual codification of a type of relationship (one, say, of sympathy or compassion), but is an embodied, sensory quality of relationship. It is, as Levinas notes, the 'signification of the sensible' (Levinas, 1998, p. 63). As Joel Krueger (2013) writes:

But like sensibility, proximity for Levinas is not a cognitive phenomenon (i.e., the construction of an ego endowed with knowledge). It is related to our prereflective sensibility, and rooted in the origins of our bodily subjectivity .... what this seems to mean is that the original basis of human ethical relationships is a felt, interpersonal resonance at the level of the body (p. 65).

Indeed, the language Levinas uses to portray this embodied sensibility in proximity often revolves around skin, caress, haemorrhaging, tasting, exposure and nakedness. After all, 'a subject is of flesh and blood' (Levinas, 1998, p. 77). Proximity is not solely about a fixed spatial distancing but about the movement inherent in approaching the other. Levinas writes, 'Proximity, as the "closer and closer", becomes the subject' (1998, p. 82).

Thus, proximity is the movement of subjectivity; the subject appears against a changing horizon of relationality - a relationality that is not marked by specific content, such as empathy, but simply by the sensible experience of contact. It is this felt, embodied experience made possible only by the space between the subject and the Other which ushers in our responsibility. As Kreuger (2013) writes:

According to Levinas, then, proximity specifies the experiential character of interpersonal space. In other words, it specifies the primitive awareness that we have of ourselves as participatory members of a human community, as creatures enmeshed with and reliant upon other creatures to whom we have an obligation and for whom we are 
responsible. Therefore, if sensibility, according to Levinas, is a transmodal, world-directed openness at the deepest levels of our bodily encounters with the world, proximity is the blossoming of this bodily subjectivity into a robust intersubjectivity. Proximity is the uniquely human quality of Levinasian sensibility ... According to Levinas, the fact of our embodiment and social situatedness are not neutral features of human reality, but instead, are affectively and ethically charged structures that knit us into living communities alongside other bodily subjects. We embody ethical relations from the very start (p. 66).

And yet, such relations are not about freeing the subject from suffering, as we find in Theravada Buddhism. Responsibility for the other is born out of the embodied demands made upon the ego through the encounter with the Other. There is no soteriology in the Buddhist sense. There is a harshness to Levinas's conception that places the subject in a relentless cycle of obligation. The passivity required to receive the teaching of alterity places the Other in a position of height, in a position of command. The Other is thus a source of wonder, but also a source of pain and torment. $\mathrm{He}$ writes of the subject's 'exposure':

Vulnerability, exposure to outrage, to wounding, passivity more passive than all patience, passivity of the accusative form, trauma of accusation suffered by a hostage to the point of persecution, implicating the identity of the hostage who substitutes himself for the others: all this is the self, a defecting or defeat of the ego's identity (1998, p. $15)$.

Thus, there is a suffering here in responsibility, too. A suffering that is carried like a burden, but one that is necessary if the ego is to unravel and an ethical subject is to emerge. In other words, such defeat is a necessary feature of responsibility. Yet, the one crack in the tough carapace of Levinasian responsibility is that there is not only suffering, but also enjoyment. Not the kind of sacrificial pleasure one takes in renouncing the ego, but that the giving up of something for the other requires that one has enjoyed that something in the first place, otherwise it is not a 'giving up' at all. 'It is a passivity of being-for-another, which is possible only in the form of giving the very bread I eat. But for this one has to first enjoy one's bread, not in order to have the merit of giving it, but in order to give it with one's heart, to give oneself in giving it. Enjoyment is an ineluctable moment of sensibility' (1998, p. 72). Thus, unlike Buddhist soteriology as discussed above, the subject is condemned to a responsibility for the other, not out of choice or reasoning, but because the encounter with the other impinges upon me, through my senses, and it is this impingement to which I am compelled to respond.

For Levinas, 'There is a paradox in responsibility, in that I am obliged without this obligation having begun in me, as though an order slipped into my consciousness like a thief, smuggled itself in ...' (1998, p. 13). Sneaking up on us, responsibility is not about pure awareness, but a moment when the subject is seized by the other and is called upon to respond. This 
response, moreover, is not purely about cognition, but about an attending to my implication in the relation I have to the Other. Thus, the quality of my response is conditioned by how well I attend to my attending-how well I 'recollect' or am mindful of what it takes to be attentive to the Other. And here the resonances with Buddhism resound once again. As Roger Simon puts it, the quality of response requires being 'awakened to an attending to my attending' (2000, p. 19). This awakening is not a form of cognition or consciousness in the narrow sense, but signals an awareness that compels me toward an ethical attentiveness to the other. In this way, attending to my attending, and waking up to the importance of this attending, is to remain receptive and open to the provocation that the encounter with the other brings. That is, awakening does not 'reach after fact and reason' in order to codify my response to the other. Rather, attending to the other is only possible to the extent I can bear the vulnerability and exposure as a felt experience occasioned by the encounter. It is this sensibility that leads to an ethical practice of life.

\section{AN EDUCATION IN NEGATIVE CAPABILITY}

Before turning directly to education, allow me to sum up the positions thus far. As we have seen, both the Buddhist and the Levinasian self is ineluctably bound, and physically so, to its encounters with and in the world. They are subject to the changes of those encounters as well as to their changing experiences within them. For Theravada Buddhism, it is the different attachments arising out of sensate experiences that set the chain of identity building on its way. For Levinas, it is the ways in which the encounter with the other occasions sensate experiences, such as vulnerability and exposure, that lead to my subjecthood. For both, what needs to take place if an ethical orientation to the world can emerge is the depositioning of the self (Buddhism) and ego (Levinas). It is only by stepping aside, so to speak, in realising my implication with others in the world that I begin to live a life of ethical import. Ethics here is not rooted in principles or knowledge, but in an embodied, felt experience of the world.

Nonetheless, a significant difference in the two positions, and one that has direct bearing on education, is the path we take in relation to the encounter itself. ${ }^{10}$ For Levinas, that path is primarily one of 'awakening to an attending of my attending' based on a receptivity to the provocation of the other, while for Buddhism that path is defined as one of meditation and Dhamma practice based on facing the attachments I have to my contact with the world. What this means is that for Levinas, ethics, like sensation, breaks through conventional systems, becoming a momentary disruption in the life of the everyday. At most, Levinas suggests that we can awaken to our attending in order to develop a sensitivity to the situation at hand, to the other to whom my response matters. He stops short of suggesting that responsibility can be 'cultivated' in any way, since his project is to avoid the trappings of telling others what to do and how to do it. Instead, in focussing on the very ethical structure of subjectivity, and not on moral practice, his work opens up questions of how to rethink what is possible 
in education. In contrast, Buddhism offers a definite path, both for living and for developing a capacity to become aware through meditation. In this sense, Buddhism speaks more explicitly about what we can do and how we can do it, while acknowledging that the path will take its specific turns and detours depending on the self who is practicing.

With respect to education, my task has been to propose another way of thinking about encounters beyond the confines of the current narrowing of them into cognitive, measurable outcomes. In order, I think, to develop an ethos that includes the wellbeing of children and youth, and to help them negotiate their relations to, in and with the world responsibly, there is much that an education in negative capability has to offer. Not only would this entail an openness to the mysteries and doubts of life, as Keats suggests, but it would also include an explicitly ethical reaching out toward others. As both Levinas and Buddhism have shown, this is not done solely through any technical training in attention - although this could be part of it - but through enabling a quality of life where reflection, attending to, and recollection are practices seen in terms of their relationality. That is, while vipassana meditation is a solo activity, it is directed toward a larger sense of living of life in the world with others. And while Levinas's ethics of alterity might seem abstract in the extreme, it speaks to the real sensate experiences each of us has in meeting an other-experiences which I cannot predict or control. Thus, an education in negative capability would give us a new ground for thinking what our purposes in education could be and which practices could support those purposes.

While not wanting to detail precisely what this would look like I do wish to suggest that such an education would make room for spaces of contemplation and give time in the curriculum to explore our embodied ways of being in the world. This would not necessarily require overly formalistic practices, but would nonetheless offer students and teachers time for silent reflection, for quietly exploring sensation, and offer encouragement to 'see' their attachments as part of the necessary matrix of life. This would be part of what Leah Kalmanson calls " "alterity practices": strategies - embodied ritual practices - that develop our capacity for compassion and mindfulness and thereby train us to maintain the urgency of the face-to-face relation ...' (2012, p. 125). Alterity practices would make evident the interdependency of self and other, and seek to allow the self to be moved, to be provoked - to be bowled over even - while also offering a concrete approach for becoming aware of those experiences without having to 'categorise' them. Education would then become more directly engaged with the mystery and ambiguity of life. And even if most of the time in classrooms is spent on knowing more and knowing better, these small breaks with the system are necessary for nourishing life beyond cognitive performance. Most importantly, they make our systems of education more responsive to the actual lived realities of students by engaging their existential sensibilities, perplexities, and wonder and by enabling them to face the unknown with an open spirit, however difficult that might be. For if education is going to truly matter to students, it cannot be simply about 'preparing' for life, but about engaging the very life that students are living - right here, right now. 


\section{Correspondence: Sharon Todd, Maynooth University, Department of Edu- cation, Maynooth, Co., Kildare, Ireland. \\ E-mail: Sharon.todd@nuim.ie}

\section{NOTES}

1. For a similar understanding in different educational contexts, see David McCormack's (2013) and Richard Smith's (2005) uses of negative capability to depict uncertainty as central to personal transformation and to redefining the purposes of the university, respectively.

2. This is where a Buddhist idea of unity of self with the world seems to come into direct conflict with the Levinasian position of radical alterity; that is, that two beings may share many things and are interdependent, but singular existence is not one of them. Thus, for Levinas, his philosophy is based on an interdependency that is nonsame, while Buddhism often sees interdependence with the world as virtually synomous with nonduality. See Kalmanson, 2010.

3. Indeed, these are alternative translations of $d u k k h a$.

4. I will be using the term 'self' and 'I' interchangeably. Self here refers to the sense of self that is constituted through our conditioned being in the world. It does not refer to a transcendent self, such as we find in the Brahmanic notion of atman, for example. See Sarath's article in this issue for a notion of self from the perspective of Vedanta.

5. But as the Buddha declares in the Khandhasmyutta, "When it is said, "The way leading to the origination of identity," the meaning here is this: a way of regarding things that leads to the origination of suffering' (Bodhi, 2000, p. 884). Identity might be relational, but it is also our source of suffering and therefore becomes the focus for liberation.

6. These educational movements operate to construct alternative discourses, whereas practices of mindfulness seek to detach from discourses altogether and to observe our relations to them. This point was suggested to me by Oren Ergas.

7. For a definitive translation and commentary see Anālayo, 2003. For a discussion of what the Sutta means for specific practices of vipassana meditation, see Goldstein, 2013.

8. See, in particular, his fulsome discussion in Chapter 1 (Anālayo, 2003).

9. I will be using 'self' and 'subject' interchangeably with respect to Levinas's depictions of individual subjectivity. Levinas refers mainly to 'ego' and 'I' as those totalising positions which more closely resemble the Buddhist sense of 'self', and so I will follow this usage.

10. I am not referring to the Buddhist 'eightfold path' here, but signalling merely the different tacks the two positions as outlined above take with respect to the encounter.

\section{REFERENCES}

Anālayo. (2003) Sattipatthāna: The Direct Path to Realization (Birmingham, Windhorse).

Batchelor, S. (2012) The Phenomenology of Meditation. Dharma talk. Available at: www.dharma seed.org/teacher/169/talk/16036

Bazzano, M. (2013) This Very Body, the Buddha, Sexual and Relationship Therapy, 28.1-2, pp. $132-140$.

Bodhi, B. (2000) The Connected Discourses of the Buddha: A Translation of the Samyutta Nikaya (Boston, MA, Wisdom Publications).

Britzman, D. (2009) The Very Thought of Education: Psychoanalysis and the Impossible Professions (Albany, NY, SUNY Press).

Goldstein, J. (2013) Mindfulness: A Practical Guide to Awakening (Boulder, CO, Sounds True).

Kalmanson, L. (2012) The Messiah and the Bodhisattva: Anti-Utopianism Re-Revisited, Shofar: An Interdisciplinary Journal of Jewish Studies, 30.4, pp. 13-125.

Kalmanson L. (2010) Levinas in Japan: The Ethics of Alterity and the Philosophy of No-Self, Continental Philosophical Review, 43, pp. 193-206.

Kreuger, J. (2013) The Space between Us: Embodiment and Intersubjectivity in Watsuji and Levinas, in: L. Kalmanson, F. Garrett and S. Mattice (eds) Levinas and Asian Thought (Pittsburgh, PA, Dusquesne University Press), pp. 53-77.

Levinas, E. (1969) Totality and Infinity, A. Lingis, trans. (Pittsburgh, PA, Duquesne University Press). 
Levinas, E. (1987) Time and the Other, R. Cohen, trans. (Pittsburgh, PA, Duquesne University Press).

Levinas, E. (1998) Otherwise Than Being or Beyond Essence, A. Lingis, trans. (Pittsburgh, PA, Duquesne University Press).

McCormack, D. (2014) Trina Chéile: Reflections on Journaling in the Border Country of Doctoral Research, Studies on the Education of Adults, 46, pp. 163-176.

O’Donnell, A. (2014) Another Relationship to Failure: Reflections on Beckett and Education, Journal of Philosophy of Education, 48.2, pp. 260-274.

Simon, R. (2000) The Paradoxical Practice of Zakhor: Memories of 'What Has Never Been My Thought or My Deed', in: S. Rosenberg, R. Simon and C. Eppert (eds) Between Hope and Despair: Pedagogy and the Remembrance of Historical Trauma (Lanham, MD, Rowman and Littlefield), pp. 9-26.

Smith, R. (2005) Dancing on the Feet of Chance: The Uncertain University, Educational Theory, 55.2, pp. 139-150.

Todd, S. (2003) Learning from the Other: Levinas, Psychoanalysis and Ethical Possibilities in Education (Albany, NY, SUNY Press).

Verter, M. (2013) The Flow of the Breath: Levinas Mouth-to-Mouth with Buddhism, in: L. Kalmanson, F. Garrett and S. Mattice (eds) Levinas and Asian Thought (Pittsburgh, PA, Dusquesne University Press), pp. 225-239. 